UDC 006.03:528.4-051(477+438)

\title{
COMPARATIVE ANALYSIS OF CERTIFICATION REQUIREMENTS FOR LAND GOVERNORS AND GEODESISTS IN UKRAINE AND POLAND
}

\author{
Kharytonenko R. A, PhD in Economics \\ E-mail: kharytonenkor@gmail.com \\ Vysidalko A.A. specialist \\ E-mail: anastasia.visidalko@gmail.com
}

Trokhymchuk A. A., specialist

E-mail:trohim11121997@gmail.com

The Institute of Land Management of National Academy of Agrarian Sciences of

\section{Ukraine}

An analysis of scientific research on professional training and qualification certification of land surveying engineers, surveying engineers in Ukraine and abroad on the example of Poland. The need for studying, borrowing the experience of one of the countries of the European Union and further adaptation of this certification in Ukraine is substantiated.

Qualification requirements for certification of land surveying engineers, surveying engineers in Ukraine and Poland are considered. A comparison of the qualification exam for a certified land surveyor is given. An analysis of the comparison of similar and different indicators for obtaining a certificate of land surveying engineer, surveying engineer in Ukraine and Poland. Professional length of service, education, form of examination, number of questions submitted for written part and total number of questions for examination, term of necessity of confirmation of qualification, availability of legal capacity and bringing to administrative or criminal responsibility connected with professional activity are analyzed. Emphasis is placed on the quality of qualification selection of certified land surveying engineers, surveying engineers.

Suggestions for reviewing the requirements for obtaining a qualification certificate of a land surveying engineer in Ukraine are presented. In the future, the revision of qualification certification requirements will help create objective equal 
opportunities for land relations specialists, ensure quality implementation of various complexity and specialization in geodesy and land management, as well as adaptation of certification with our western neighbors - the European Union.

Keywords: certificate of land surveying engineer, surveying engineer, certification, land management, foreign experience, professional practice.

Formulation of the problem. Highly skilled workers are needed for the development of each branch of production. Land management is no exception, as this profession was in demand when there was a need for land division and settlement of land relations. The land reform, which is in its final stages, and the current administrative transformations are being carried out for the final transition from the Soviet type of land relations to the modern model of management. This affects the compliance of personnel in the field of land management in accordance with modern challenges. Therefore, the path of becoming a modern land surveyor in Ukraine requires rethinking and improvement [1]. An example to follow is the advanced countries of the world, which have gone through a similar path of economic transformation in land relations. It should be borne in mind that these models of land relations are much older than the independence of Ukraine, so the objective borrowing of their experience in our field can not be applied in full. The transition of the former countries of the socialist camp to democratic development also required changes in the sphere of land relations. Given the economic efficiency achieved by the countries of the former Warsaw Pact, and now members of the European Union, we can compare the path of becoming a certified land surveyor. Take, for example, Poland, one of our western neighbors on the border.

Analysis of recent research and publications. The following scientists conducted research on professional training in higher educational institutions and qualification certification of land surveying engineers in Ukraine and abroad: Tretyak AM, Tretyak VM, Dorosh JM, Dorosh OS, Drebot O .V., Borovy VO, Krasnolutsky OV, Ryabchiy VV, Rusina NG, Nikolaychuk KM etc. 
In particular, Tretyak AM, Tretyak VM, Dorosh JM, Dorosh OS studied the state and problems of supply and demand of the land surveyor profession today. They proved that the profession of land surveyor needs re-profiling and expansion of skills in accordance with modern challenges [2].

Drebot OV, Krasnolutsky OV considered the problems of land management education in Ukraine and the need for integrated approaches to adapt the acquired skills in the training of specialists in the field of land management with European education [3].

Nikolaychuk KM researched the problems of professional training of land surveying engineers in higher education institutions. It considers the stages of obtaining the qualification of a certified land surveyor in Ukraine [4].

Borovy VO drew attention to the need to change during the certification of land surveying engineers and surveying engineers. He considered the problems and proposals for the quality of training of specialists in the field of "geodesy, cartography and land management" [5].

Ryabchiy VV researched the problem of modern training of students in the field of land management, qualification requirements for obtaining a certificate of land surveying engineer or surveying engineer.He also covered the practical aspects of the qualification commission of the State Geocadastre, which deals with certification [6].

Rusina NG considered the general tendencies and differences in the educational professional training of land managers in Ukraine and compared them with the Polish experience. She focused on the historical and theoretical aspects of training land managers in Poland. [7] . But the actual executors and responsible for the implementation of land management on the ground are certified land surveyors.

Therefore, the issue of the quality of qualification selection of certified land surveyors and adaptation of this certification with neighboring countries of the European Union needs further attention and study.

The purpose of the article is to conduct a comparative analysis of qualification certification of land surveying engineers, surveying engineers in Ukraine and Poland. 
Materials and methods of research.To obtain the planned results, which will correspond to the name and purpose of the study, the scientific article will use the generally accepted methods of scientific knowledge, which include the method of analysis and the method of comparative analysis. In particular, the method of analysis will allow us to divide the subject of knowledge "certification" into separate components. The method of comparative analysis will complement the previous method and will identify differences and formulate proposals for improving the certification of land surveying engineers, surveying engineers in Ukraine.

Results of research and discussion. Classification certification of land surveying engineers and surveying engineers is carried out in accordance with the following regulations: Law of Ukraine "On Land Management" [8], Law of Ukraine "On State Land Cadastre" [9], Law of Ukraine "On Amendments to the Land Code of Ukraine and other legislative acts on improving the management system and deregulation in the field of land relations "[10], Order of the Ministry of Agrarian Policy of Ukraine dated 28.07.2017 № 392" On certification of land surveying engineers and surveying engineers "[11].

Qualification certification is a necessary condition for the provision of land management documentation services carried out by the State Service of Ukraine for Geodesy, Cartography and Cadastre. The State Geocadastre certifies and maintains a register of land surveying engineers and surveying engineers. In Ukraine, a land surveyor who has passed the qualifying exam receives a certificate confirming his ability to independently compile land management documentation. According to Article 66 of the Law of Ukraine "On Land Management" the main qualification requirements for obtaining a certificate of land surveyor are:

«A copy of the diploma of higher education at the educational and qualification levels of specialist (master) in the field of professional specialty land management / land management;

- work experience in a professional specialty of at least 1 year;

- a copy of two complete completed projects, (schemes) of land management or technical documentation, in which the land surveyor participated; 
- written recommendations from the place of work (internship)» [8].

«Persons who have limited legal capacity or are declared incapable by a court decision and / or do not meet the requirements» [8] specified in Article 66 of the Law of Ukraine «On Land Management» are not allowed to take the exam to obtain a certificate of land surveyor.

«Qualification exam is a procedure during which the professional competence of a person, the level of qualification and knowledge as a performer of land management work is confirmed» [8]. If a person meets the qualification requirements, he is allowed to take a qualifying examination, which consists of a test part and an interview.

The official website of the State Geocadastre provides a list of the questions themselves (without test options), which are submitted for the exam for a certified land surveyor. This list of questions is divided into questions on land legislation and land management - 500 questions, on the section of geodesy - 60 questions. Also on the website of the State Geocadastre there is a list of questions for advanced training of certified land surveying engineers - 1000 questions [12]. During the exam, the system will select only 50 questions from the total number of covered questions, most of them with the proposed answer options, ie in test form. At least 30 questions must be answered correctly in order to be admitted to the interview [6].

After successfully passing the test part and the interview at the qualifying exam, the person receives a qualification certificate of land surveyor indefinitely, subject to advanced training every 4 years. Due to this, a certified land surveyor gets the right to independently perform the following types of land management and land assessment: «topographic, geodetic and cartographic works, land inventory, quality control of soil, geobotanical and other land surveys in land management» [8].

In Poland, land surveying engineers and surveying engineers, unlike in Ukraine, are not certified separately. According to information from the official website of the Main Department of Geodesy and Cartography of Poland (abbreviated - Polish GUGIK) professional qualification (certification) in the field of geodesy and cartography is carried out by a certified surveying engineer (Polish inżynierowie 
geodeci) in the following areas: geodetic situational and height measurements , implementation and carrying out of inventory measurements; delimitation and division of real estate (land) and preparation of documentation for legal purposes; geodetic investment service; geodetic arrangement of agricultural and forest plots; basic geodetic measurements; map editing; photogrammetry and remote sensing [13]. According to Polish law, «preparation of documentation for legal purposes» refers to land management documentation performed by certified surveying engineers (Polish: inżynierowie geodeci). The future certified surveying engineer in Poland can, according to the results of certification, receive only one of these areas of professional activity, in contrast to Ukraine, where the received certificate gives the land surveyor the right to perform all types of land management work.

If necessary, to expand the list of professional activities, the interested person has the right, subject to qualification requirements, to pass another qualification exam.

Qualification requirements for certification as a surveyor in Poland are governed by the following legislation: - Geodetic and cartographic law; Law of June 13, 2013 on amendments to acts regulating activities in certain professions; Order of the Minister of Development of July 28, 2020 on professional qualifications in the field of geodesy and cartography [13].

Basic qualification requirements for obtaining the certification of a surveying engineer in a certain area of professional activity [13]:

- have full legal capacity;

- have not been punished for crimes against the activities of state institutions and local self-government, for crimes against the administration of justice, for crimes against the authenticity of documents, for crimes against property, for crimes against economic transactions, for crimes against trade in money and securities or for fiscal crimes;

- have higher or secondary education in geodesy, in the field of map editing, in the field of photogrammetry and remote sensing; 
- completed doctoral studies (professional degree) - professional practice is not required; completed master's degree - 1 year of professional practice; completed engineering studies (bachelor) - 2 years of professional practice; graduated from technical school (college) (junior specialist) - 6 years of professional practice.

Thus, holders of academic title can obtain a professional qualification in the above areas of professional activity without the obligation to have a professional practice.

Also, the chief surveyor in Poland may, in justified cases, at the request of the professional in the above ranges, consider the possibility of obtaining other relevant education, geodetic or cartographic professional practice that meets the qualification requirements for higher or secondary geodetic education [13].

The qualifying examination in Poland consists of written and oral parts (interviews). The written part of the exam - 60 test questions and 3 open questions related to a specific area of professional activity. The total number of questions submitted for the exam (from 460 to 600 questions) [13, 14]. The difference in the number of questions is explained by the change in their set each year. After obtaining the qualification, a surveying engineer can also perform independent functions in the field of geodesy and cartography, which means [13]:

- management of geodetic and cartographic works under the condition of reporting to the state geodetic and cartographic resource and direct supervision over them;

- carrying out the activity of an expert in the field of geodetic and cartographic works under the condition of reporting to the state geodetic and cartographic resource;

- acting as an inspector for supervision in the field of geodesy and cartography;

- carrying out technical and administrative activities related to the delimitation of real estate;

- performing geodetic and cartographic works necessary for making entries in land and mortgage registers and works that may endanger human health and life. 
Thus, we can summarize and make a comparison of the qualification certification of a land surveying engineer in Ukraine and Poland. (tabl. 1).

Table 1. Comparison of requirements for obtaining a land surveyor certification in

Ukraine and Poland

\begin{tabular}{|c|c|c|c|}
\hline № & indicator & Ukraine & Poland \\
\hline 1 & $\begin{array}{l}\text { Professional work } \\
\text { experience }\end{array}$ & Not less than 1 year & $\begin{array}{cr}\bullet & \text { completed } \\
\text { doctoral } & \text { studies }\end{array}$ \\
\hline 2 & Education & $\begin{array}{c}\text { Higher education, } \\
\text { educational level not lower } \\
\text { than a specialist, master }\end{array}$ & 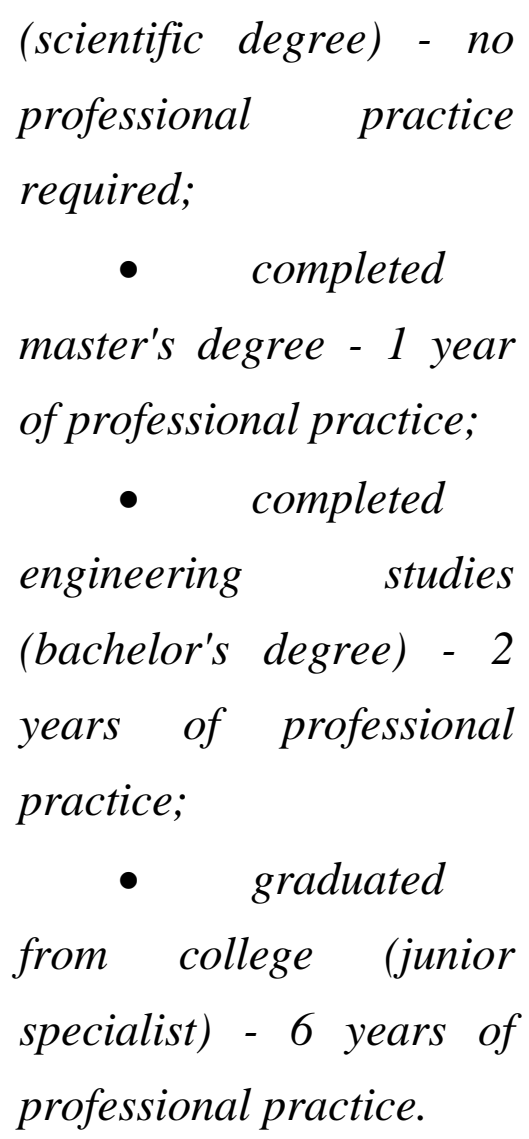 \\
\hline 3 & Exam format & $\begin{array}{c}\text { Written (test), oral part } \\
\text { (interview) }\end{array}$ & $\begin{array}{c}\text { Written (test), oral part } \\
\text { (interview) }\end{array}$ \\
\hline 4 & $\begin{array}{l}\text { Number of questions in } \\
\text { the written part (test) }\end{array}$ & 50 & 60 \\
\hline 5 & $\begin{array}{l}\text { Total number of } \\
\text { questions taken } \\
\text { on the exam }\end{array}$ & $560-1000 *$ & Up to about $600 *$ \\
\hline 6 & $\begin{array}{l}\text { The right to } \\
\text { independently develop } \\
\text { land management }\end{array}$ & $\begin{array}{c}\text { For all types of land } \\
\text { management works in } \\
\text { accordance with Article } 25\end{array}$ & $\begin{array}{c}\text { Only for a certain type of } \\
\text { work, ie for which a } \\
\text { certificate has been }\end{array}$ \\
\hline
\end{tabular}




\begin{tabular}{|c|c|c|c|}
\hline & documentation & $\begin{array}{c}\text { of the Law "On Land } \\
\text { Management" }\end{array}$ & received \\
\hline 7 & $\begin{array}{l}\text { The period after which } \\
\text { the certificate expires } \\
\text { and there is a need for } \\
\text { training }\end{array}$ & Every 4 years & Every 3 years \\
\hline 8 & To have full capacity & + & + \\
\hline 9 & $\begin{array}{l}\text { Were not punished for } \\
\text { crimes against the } \\
\text { activities of state } \\
\text { institutions and local } \\
\text { self-government, for } \\
\text { crimes against the } \\
\text { administration of } \\
\text { justice, for crimes } \\
\text { against the authenticity } \\
\text { of documents, for } \\
\text { crimes against property, } \\
\text { for crimes against } \\
\text { economic transactions, } \\
\text { for crimes against trade } \\
\text { in money and securities } \\
\text { or for fiscal crimes }\end{array}$ & $\begin{array}{c}\text { Not provided by Article } 66 \\
\text { of the Law "On Land } \\
\text { Management" }\end{array}$ & + \\
\hline
\end{tabular}

Note * - each year the number of questions that are presented for review and preparation for the exam changes

Compiled by the authors based on sources $[6,8,9,10,11,12,13,14]$

Given the similarities with most indicators for obtaining the certification of a land surveying engineer in Ukraine and Poland, it is worth noting the following differences:

1. After obtaining certification in Poland there are restrictions on the types of work performed. That is, a certified surveying engineer in Poland has the right to 
make only the type of documentation for which he was issued a certificate. For other types of documentation, it is necessary to have the appropriate specialization at the educational level and internships for persons from a private company or (government) local government body that already have this specialization. This practice helps to increase the quality of land management, because the contractor must have more knowledge of specific types of land management documentation. In Ukraine, in contrast to Poland, there is a practice where a person receives a qualification certificate and can perform all types of land management work. However, the quality of work performed as an individual entrepreneur, private organization or research enterprise may differ significantly. For example, types of land management documentation "feasibility studies for the use and protection of lands of administrative-territorial units; ecological and economic substantiation of crop rotation and land management; on the organization and establishment of the boundaries of nature reserves and other environmental purposes, health, recreational, historical and cultural, forestry lands, water fund lands and water protection zones, restrictions on the use of lands and their regime-forming objects "[8] require specialized knowledge for development and quality implementation. According to Article 66 of the Law of Ukraine "On Land Management": "The presence of a qualification certificate is a necessary condition for the provision of services for the preparation of land management documentation and a guarantee of quality land management" [8]. So, how can the quality of land management documentation for specialized projects be objectively guaranteed, when in addition to a certified land surveyor it is necessary to involve other specialized specialists in the relevant field (research agricultural enterprises, environmental, forestry...) [1 ]. However, today, according to the certificate of a land surveyor, an individual entrepreneur, in whose staff only he is an employee, he legally performs these works.

2. Upon obtaining a certificate of land surveying engineer in Ukraine and Poland, there is professional experience and education. In Ukraine, one of the requirements to obtain a certificate of land surveying engineer is a complete higher education and work experience of at least 1 year, as well as confirmed participation in 
the development: at least two projects or technical documentation on land management $[6,8]$. Objectively, with a work experience of 1 year in a professional specialty, a person is not able to comprehend and participate in the development of all types of land management documentation. Today, the greatest demand is for the development of "land management projects for land allocation, for the development of technical documentation on land management for the establishment (restoration) of land boundaries in kind (on the ground), as well as for the division and consolidation of land" [8 ]. Of course, there are other types of land management work, but they are not so common. Thus, the question arises as to the objectivity of providing the opportunity to obtain a qualification certificate of a land surveying engineer for the development of all types of land management documentation, and not the individual types for which the person trained and developed the documentation.

In Poland, it is possible to obtain a qualification certificate for persons depending on the level of education, starting with a junior specialist and bachelor, in contrast to Ukraine, where a qualification certificate is provided for persons with a master's degree (specialist) with 1 year of professional practice. However, in Poland the duration of work experience for a junior specialist increases - 6 years of professional practice, bachelor - 2 years of professional practice, master - 1 year of professional practice, obtaining a scientific degree of professional practice does not require specialization $[13,14]$. Thus, the equality of all those wishing to obtain a qualification certificate is preserved, as a person can acquire professional skills not only while studying at a higher educational institution, but also to obtain them while working in a professional field.

3. In the land legislation of Ukraine, in particular in Article 66 of the Law of Ukraine "On Land Management", which regulates training and staffing in the field of land management, there are no restrictions for persons obtaining a certificate of land surveyor who were punished for crimes against state institutions and local government, for crimes against the administration of justice, for crimes against the authenticity of documents, for crimes against property, for crimes against economic transactions, for crimes against trade in money and securities or for fiscal crimes. 
4. The new Law of Ukraine № 1423-IX of 28.04.2021 "On Amendments to Certain Legislative Acts of Ukraine on Improving the Management and Deregulation System in the Sphere of Land Relations" amends Article 51 of the Law of Ukraine "On Topographic, Geodetic and Cartographic Activities" - Professional training and staffing in the field of topographic, geodetic and cartographic activities [10]. For the first time at the legislative level it is determined that topographic and geodetic and cartographic works will be carried out in three areas: "a) basic geodetic works; b) national topographic surveys; c) engineering surveys for construction and large-scale topographic surveys "[10]. Lawmakers have determined that topographic, geodetic and cartographic works according to their specifics, requirements and quality of execution should be divided in the relevant areas. It was also determined for the first time that passing the qualification exam for a certified surveying engineer will be carried out in the relevant area of professional activity - "basic surveying work; national topographic surveys; engineering surveys for construction and large-scale topographic surveys "[10]. The corresponding trend in the division of professional activities of surveying engineers is a timely step towards optimization and quality of work based on the experience of other countries. However, it should be noted that this professional division of certified surveying engineers in accordance with the Law of Ukraine № 1423-IX of 28.04.2021 needs to be clarified and supplemented taking into account the differences of all types of topographic and geodetic and cartographic works, the opinion of the professional community and scientific opinion on the distribution of such works on their specific features, level of complexity and scale of such works.

Types of land management documentation should also be divided according to certain areas of specialization, taking into account the levels of spatial planning in the new administrative-territorial division, scale and requirements for specific types of land management documentation. The qualification exam for obtaining the certificate of a land surveyor engineer should similarly pass according to the appropriate distribution of such types of land management works according to their specific features, level of complexity and scale. 
Conclusion. Each certified land surveyor guarantees high-quality execution of land management documentation. The professional and qualification qualities of a land surveyor should correspond to the possibility of developing a certain type of land management documentation.

Today, the implementation of topographic, geodetic, cartographic and work related to the development of land management documentation differ significantly in specialization, level of complexity, scale of implementation. To perform various types of work in the field of land management, geodesy, it is necessary to review and improve the existing procedure for qualification of certified surveying engineers and land surveying engineers.

Suggestions. In order to create conditions that will ensure the implementation of different complexity and specialization of work related to geodesy and land management, in our opinion, it is necessary to take the following actions:

- to carry out the qualification examination and issue the relevant certificate in accordance with each type (or group of types) of land management documentation on a separate set of questions that should correspond to these areas of land management, land cadastre and assessment activities in the field of land assessment;

- when taking the qualification exam for each type (or group of types) of land management documentation to take into account what type of land management documentation was developed by the land surveyor and accordingly has professional skills and the right to pass the classification exam for this type of work;

- in case of transition to detailing by complexity, specific features of types of land management to provide an opportunity to obtain a qualification certificate to persons with a bachelor's degree, to independently compile land management documentation, which has a «lower» level of complexity which can include, for example, technical documentation land management on the establishment (restoration) of the boundaries of the land in kind (on the ground), technical documentation on land management on the division and 
consolidation of land. Duration of work experience in a professional field, depending on the educational level can be borrowed from a similar experience in Poland;

- to ensure guarantees of work performance and their quality, review the requirements for natural persons-entrepreneurs and legal entities that may be involved in the development of land management documentation in terms of types of work, their complexity and needs of hardware, software, number and specialization of specialists needed to ensure timely and quality implementation of land management, land cadastral and valuation activities in the field of land valuation;

- impose restrictions on persons obtaining a land surveyor's certificate who have been punished for crimes against the activities of state institutions and local self-government, for crimes against the administration of justice, for crimes against the authenticity of documents, for crimes against property, for crimes against economic transactions, for crimes against trade in money and securities or for fiscal crimes.

- needs to clarify and supplement the professional division of certified surveying engineers, defined in accordance with the Law of Ukraine № 1423-IX of 28.04.2021, taking into account the differences of all types of topographic and geodetic and cartographic works, the opinion of the professional community and scientific opinion on the distribution of such works according to their specific features, level of complexity and scale of such works.

\section{References}

1. Dorosh Y.M., Dorosh O.S., Ibatullin Sh.I., Tarnopolskyi A.V., Shkuratov O.I., Avramchuk B.O., Kharytonenko R.A. (2020). Inventaryzatsiia zemel naukovykh ustanov, pidpryiemstv ta orhanizatsii Natsionalnoi akademii ahrarnykh nauk Ukrainy: metod. posib [Inventory of lands of scientific institutions, enterprises and organizations of the National Academy of Agrarian Sciences of Ukraine: methodical manual] Kyiv, Ukraine: FOP Yamchynskyi O.V., 133. 
2. Tretiak A.M., Tretiak V.M., Dorosh Y.M., Dorosh O.S. (2018). Profesiia zemlevporiadnyk na rynku pratsi: stan ta problemy popytu i propozytsii [Land manager profession on labor market: condition and problems of request and demand]. Zemleustrii, kadastr i monitorynh zemel. 1. doi: http://dx.doi.org/10.31548/zemleustriy2018.01.011

3. Drebot O.V., Zubova O.V., Lukianenko O.P., Krasnolutskyi O.V. (2019). Zemlevporiadna osvita Ukrainy $\mathrm{v}$ umovakh yevrointehratsii [Land management education of Ukraine in conditions of eurointegration]. Zemleustrii, kadastr i monitorynh zemel. 1. doi: http://dx.doi.org/10.31548/zemleustriy2019.01.07

4. Nikolaichuk K.M. (2013). Zakonodavchi zminy v pidhotovtsi spetsialistiv-zemlevporiadnykiv [Legislative changes in the training of land managers]. Seriia «tekhnichni nauky». Vypusk 1(61), 216-223.

5. Borovyi V.O. (2013). Sertyfikatsiia inzheneriv-heodezystiv ta inzheneriv-zemlevporiadnykiv. Shcho treba zminyty? [Certification of surveying engineers and land surveying engineers. What needs to change?]. Zemlevporiadnyi visnyk. 1, 13-14.

6. Riabchii V.V. (2021). Malo otrymaty sertyfikat, holovne - shchodnia pidtverdzhuvaty yoho [It was not enough to get a certificate, the main thing is to confirm it every day]. Zemlevporiadnyi visnyk. 3, 24-27.

7. Rusina N.H. (2017). Analiz navchalnykh prohram profesiinoi pidhotovky maibutnikh zemlevporiadnykiv: polskyi dosvid [Analysis of training programs for future land managers: the Polish experience]. Pedahohika formuvannia tvorchoi osobystosti u vyshchii i zahalnoosvitnii shkolakh. Vyp. 54, 213-220.

8. Zakon Ukrainy «Pro zemleustrii» redaktsiia vid 26.02.2021 r. № 858-IV. Available at : https://zakon.rada.gov.ua/laws/show/858-15\#Text.

9. Zakon Ukrainy «Pro vnesennia zmin do deiakykh zakonodavchykh aktiv Ukrainy shchodo vdoskonalennia systemy upravlinnia ta derehuliatsii u sferi zemelnykh vidnosyn» pryiniatoho vid 28.04.2021 r. № 1423-IKh. Available at : https://zakon.rada.gov.ua/laws/show/1423-20. 
10. Zakon Ukrainy «Pro Derzhavnyi zemelnyi kadastr» redaktsiia vid 27.05.2021 r. № 3613-VI. Available at : https://zakon.rada.gov.ua/laws/show/1423$\underline{20}$

11. Nakaz Minahropolityky Ukrainy «Pro pytannia sertyfikatsii inzhenerivzemlevporiadnykiv ta inzheneriv-heodezystiv» vid 28.07.2017 № 392 Available at : https://zakon.rada.gov.ua/laws/show/z1044-17\#Text

12. Derzhavna sluzhba Ukrainy z pytan heodezii, kartohrafii ta kadastru. Ofitsiinyi veb-sait. Perelik pytan na perevirku znan skladannia ispytiv sertyfikovanykh inzheneriv-zemlevporiadnykiv zatverdzhenykh rishenniam Kvalifikatsiinoi komisii vid 28.01.2021 r. 1. Available at : https://land.gov.ua/info/perelik-pytan-na-perevirku-znan-skladannia-ispytivsertyfikovanykh-inzheneriv-zemlevporiadnykiv-zatverdzhenykh-rishenniamkvalifikatsiinoi-komisii-vid-28-01-2021-1/.

13. Główny Urząd Geodezji i Kartografii: Strona główna. Oficjalna strona internetowa. Uprawnienia. Uwarunkowania prawne. Available at : http://www.gugik.gov.pl/uprawnienia-zawodowe/uwarunkowania-prawne.

14. Geodezja: praca. Ile zarabia geodeta, co robi i jak nim zostać? Available at : https://interviewme.pl/blog/geodezja-praca.

Харитоненко Р.А., Висідалко А.А., Трохимчук А.А.

ПОРІВНЯЛЬНИЙ АНАЛІЗ ВИМОГ ЩОДО СЕРТИФІКАЦІЇ ІНЖЕНЕРІВ ЗЕМЛЕВПОРЯДНИКІВ І ГЕОДЕЗИСТІВ В УКРАЇНІ ТА ПоЛЬЩІ

Проведено аналіз наукових досліджень щодо професійної підготовки $i$ кваліфікаційної сертифікації інженерів-землевпорядників, інженерівгеодезистів в Украйні та за кордоном на прикладі Польщі. Обтрунтовано потребу у вивченні, запозиченні досвіду однієї із країн Європейського Союзу та в подальшій адаптації даної сертифікащії в Україні.

Розглянуто кваліфікаційні вимоги для отримання сертифікації інженерівземлевпорядників, інженерів-геодезистів в Україні та Польщі. Наведено 
порівняння проведення кваліфікаиійного іспиту на сертифікованого інженераземлевпорядника. Проведено аналіз порівняння схожих та відмінних показників щъодо отримання сертифікату інженера-землевпорядника, інженерагеодезиста в Украйні та Польщі. Проаналізовано трудовий професійний стаж, освіту, форму іспиту, кількість питань, що виноситься на письмову частину та загальну кількість питань на іспит, термін необхідності підтвердження кваліфікації, наявність дієздатності та притягнення до адміністративної чи кримінальної відповідальності, пов'язаної із професійною діяльністю. Акцентовано увагу на питанні якості проведення кваліфікаційного відбору сертифікованих інженерів-землевпорядників, інженера-геодезиста.

Представлено пропозиції у перегляді вимог при отриманні

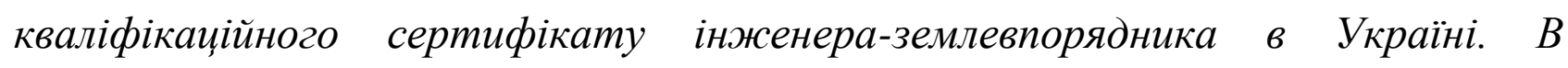
подальшому перегляд вимог кваліфікащійної сертифікачї сприятиме створенню об'єктивних рівних можливостей фахівиям земельних відносин, забезпеченню якісного виконання різної за складністю та спеціалізацією із геодезії та землеустрою, а також адаптаиії сертифікаџіï із нашими західними сусідами - краӥнами Свропейського Союзу.

Ключові слова: сертифікат інженера-землевпорядника, інженергеодезист, сертифікачія, землеустрій, закордонний досвід, професійна практика.

\section{Харитоненко Р.А, Высидалко А.А., Трохимчук А.А.}

СРАВНИТЕЛЬНЫЙ АНАЛИЗ ТРЕБОВАНИЙ ПО СЕРТИФИКАЦИИ ИНЖЕНЕРОВ ЗЕМЛЕУСТРОИТЕЛЕЙ И ГЕОДЕЗИСТОВ В УКРАИНЕ И ПОЛЬШЕ

Проведен анализ научных исследований по профессиональной подготовке и квалификационной сертификации инженеров-землеустроителей, инженеровгеодезистов в Украине и за рубежом на примере Польши. Обоснована необходимость в изучении, заимствовании опьта одной из стран Европейского Союза и в дальнейтей адаптаџии данной сертификаџии в Украине. 
Рассмотрены квалификационные требования для получения сертификаџии инженеров-землеустроителей, инженеров-геодезистов в Украине и Польше. Приведено сравнение проведения квалификационного экзамена на сертифищированного инженера-землеустрочтеля. Проведен анализ сравнения похожих и отличных показателей по получению сертификата инженераземлеустроителя, инженера-геодезиста в Украине и Польше. Проанализированы трудовой профессиональный стаж, образование, форму экзамена, количество вопросов, который выносится на письменную часть и общее количество вопросов на экзамен, срок необходимости подтверждения квалификации, наличие дееспособности и привлечения к административной или уголовной ответственности, связанной с профессиональной деятельностью. Акцентировано внимание на вопросе качества проведения квалификаиионного отбора сертифицированных инженеров-землеустроителей, инженерагеодезиста.

Представлены предложения в пересмотре требований при получении квалификационного сертификата инженера-землеустроителя в Украине. В дальнейшем пересмотр требований квалификаџионной сертификаџии будет способствовать созданию объективных равных возможностей специалистам земельных отномений, обеспечению качественного выполнения различной по сложности и специиализащии с геодезии и землеустройства, а также адаптащии сертификащии с нашими западными соседями - странами Европейского Союза.

Ключевые слова: сертификат инженера-землеустрочтеля, инженеров геодезистов, сертификация, землеустройство, зарубежный опыт, профессиональная практика. 